\title{
Language Use in a Multilingual Class: a Study of the Relation Between Bilingual Students' Languages and Their Meaning-Making in Science
}

\author{
Zeynep Ünsal ${ }^{1}$ (D) - Britt Jakobson ${ }^{1}$ • \\ Bengt-Olov Molander ${ }^{1} \cdot$ Per-Olof Wickman ${ }^{1}$
}

Published online: 28 April 2017

(C) The Author(s) 2017. This article is an open access publication

\begin{abstract}
In this study, we examine how bilingual students in elementary school use their languages and what this means for their meaning-making in science. The class was multilingual with students bilingual in different minority languages and the teacher monolingual in Swedish. The analysis is based on a pragmatic approach and the theory of translanguaging. The science content was electricity, and the teaching involved class instruction and hands-on activities in small groups. The findings of the study are divided into two categories, students' conversations with the teacher and student's conversations with each other. Since the class was multilingual, the class instruction was carried out in Swedish. Generally, when the conversations were characterised by an initiation, response and evaluation pattern, the students made meaning of the activities without any language limitations. However, when the students, during whole class instruction, were engaged in conversations where they had to argue, discuss and explain their ideas, their language repertoire in Swedish limited their possibilities to express themselves. During hands-on activities, students with the same minority language worked together and used both of their languages as resources. In some situations, the activities proceeded without any visible language limitations. In other situations, students' language repertoire limited their possibilities to make meaning of the activities despite being able to use both their languages. What the results mean for designing and conducting science lessons in a multilingual class is discussed.
\end{abstract}

Keywords Science education $\cdot$ Bilingualism $\cdot$ Language use $\cdot$ Meaning-making

Zeynep Ünsal

Zeynep.unsal@mnd.su.se

1 Department of Mathematics and Science Education, Stockholm University, SE-106 91, Stockholm, Sweden 


\section{Introduction}

Being bilingual means having two languages to use as resources when learning science (Lee 2005; Reyes 2009). This approach is of importance for linguistic development as well as students' overall achievement at school (Cummins 2005). Most of the existing studies concerning the inclusion of bilingual students' both languages in science education have been conducted in classrooms where students and teachers share the same languages (e.g. Goldberg et al. 2009; Reyes 2009; Salleh et al. 2007). However, in many countries, the class compositions are not bilingual but rather multilingual, implying that several minority languages are represented in the same class (Blackledge and Creese 2010; The Swedish National Agency for Education 2016a). In this article, we address this issue by examining bilingual students' language use in a multilingual class. We present examples from situations in which students were limited to use only one of their languages and situations where they could use both of their languages, respectively. In doing so, we examine which consequences these situations have for bilingual students' meaning-making in science class.

Several scholars have demonstrated the significance of language for learning science (Carlsen 2007; Lemke 1990; Norris and Phillips 2003; Wellington and Osborne 2001). According to Lemke (1990, p. 153), 'the mastery of science is mainly a matter of learning how to talk science'. Similarly, Wellington and Osborne (2001, p. 2) reason that 'every science lesson is a language lesson'. The language of science is viewed as difficult and abstract by many students (Lemke 1990, 1998). Science lessons contain words that are totally new to some students. In other cases, scientific concepts, for example, energy, power and work, are used differently in everyday life and in science (Wellington and Osborne 2001). As well, as stated by Lemke (1990), knowing the meaning of scientific concepts is not enough to learn science. Rather, it is also necessary to understand the relationship between the concepts and how they create larger patterns. Students need to participate in conversations where they are offered possibilities to argue, discuss, explain and generalise in order to develop a deeper understanding of science (Lemke 1990; Gibbons 2008; Webb and Treagust 2006). However, many science classrooms lack these kinds of conversations. Instead, the talk is characterised by an initiation, response and evaluation (IRE) pattern (Bleicher et al. 2003; McNeill and Pimentel 2010; Stevenson 2013). Typically, the conversation starts with a teacher initiation, often a question to which the teacher already knows the answer. The question results in a short student response, which is then evaluated by the teacher (Bellack, Kliebard, Hyman \& Smith 1966). Hence, conversations conducted by following an IRE pattern imply a reproduction of factual knowledge, limiting students' possibilities to develop a deeper understanding of the science content (Bleicher et al. 2003; Erduran et al. 2004; Lemke 1990; Wellington and Osborne 2001).

Bilingual students' achievements in science on average are lower than those of their monolingual peers, and scholars have suggested that this may be related to language, socioeconomic issues and cultural aspects (Lee and Luykx 2007; Snively and Corsiglia 2001). This article focuses on how language is related to meaning-making in science class. In many countries, science education for bilinguals is conducted monolingually and in a language students do not fully master (Lee 2005; Lee and Luykx 2007). This means that bilingual students face a dual task: they do not only need to learn the language of instruction but also a subject-specific content through the language (Gibbons 1998; Pica 2011). This issue is addressed in several empirical studies: for example, Nygård Larsson (2011) carried out a study in a Swedish upper secondary school aiming at examining the relation between language and bilingual students' learning possibilities in biology. The class consisted of both 
monolingual and bilingual students, and the lessons were conducted in Swedish. All monolingual students passed the course, while several bilingual students did not. Furthermore, half of the monolingual students and none of the bilinguals received the highest grade. An examination of the written tests, which the grades were predominately based on, showed how the students' achievements were related to their language proficiency in Swedish. Bilingual students' answers contained definitions and descriptions of biological phenomena. However, more complicated explanations and generalisations, necessary to receive the higher grades, were often missing. Nygård Larsson (2011) concludes that producing abstract science texts requires advanced language mastery, which is a limitation for many bilingual students. Similarly, Gibbons (1998) has shown how context-embedded situations, for example, handson activities, support bilingual students' learning in science, whereas less context-embedded situations, such as a writing session, is more demanding.

Numerous studies have shown how both languages for bilingual students play important roles in their learning process (e.g. Cummins 2000, 2005, 2008; Lindholm-Leary and Graciela 2006). Reyes (2009) analysed students' interaction with each other and the teacher in a 4th grade science class, bilingual in English and Spanish. The teacher mainly used Spanish in her instructions whereas the students spoke both of their languages with each other. Since some of the students had language limitations in English, Spanish enabled them to learn science in a way that might not have been possible if the lessons had been conducted exclusively in English. Furthermore, Reyes (2009) reasoned that the scientific knowledge the students gained by speaking Spanish might serve as a foundation for developing scientific knowledge in English. Consequently, she argues for the inclusion of both languages in order to enhance bilingual students' learning possibilities in science class. Another study (Goldberg et al. 2009) concerning language use was carried out in a 6th grade science class with a teacher and students bilingual in English and Spanish. The teacher mostly used English in her teaching, whereas Spanish constituted a legitimate tool for meaning-making among the students during small-group activities. The students had the possibility to choose the language that was most useful to them in the particular situation. An examination of the students' conversations revealed that Spanish was a significant resource that supported their understanding of the science content. Similarly, Warren et al. (2001) studied bilingual students' in the 5th and 6th grades. In both classes, the students used everyday reasoning and their minority languages as resources when making meaning of science.

Thus, the studies mentioned above emphasise the importance of bilingual students being given the opportunity to use both their languages in classroom communication and that everyday reasoning in the minority language is an important step towards meaning-making in the majority language. However, studies concerning bilingual students' language use are predominantly conducted in classes where students and teachers share the same languages. The purpose of this study is to take a step further by examining language use in a multilingual science class with students bilingual in different minority languages and a monolingual teacher. In doing so, the aim is to contribute to knowledge that can be used to promote bilingual students' meaning-making in multilingual science classes. The following questions are addressed:

1. How do bilingual students use their languages in a multilingual science class?

2. What are the consequences of bilingual students' language use for their meaning-making in science? 


\section{Theoretical Framework}

\section{A Pragmatic Approach}

In this study, learning is considered as occurring socially when students interact with other individuals and the physical world (Dewey 1925/1998; Säljö 2000; Wertsch 1993; Wickman 2006). According to Dewey's (1938/1997) principle of continuity, students make meaning of a situation by relating it to their earlier experiences and the purpose of the activity. This process implies a reactualisation and transformation of students' earlier experiences and has consequences for what they learn in the specific situation and in the future (Wickman 2006; Wickman and Östman 2002). Since every situation students enter means gaining new experiences, all situations involve learning (Lave and Wenger 1991; Rogoff 1990).

Dewey (1925/1998), like Wittgenstein (1953/2012), views speech as a form of action. When students are talking to someone they act in relation to them. Moreover, participating in an activity and interacting with others do not only imply using language but also other forms of communication, for example, gestures (Dewey, 1925/1998). However, for Dewey (1925/1998, p. 168), language is "the tool of tools" for communication. Both Wittgenstein (1953/2012) and Dewey (1934/1980) state that words do not have pre-existing representations or universal meanings, applicable to every situation. Wittgenstein (1953/2012) introduced the concept language game, implying that a word or an utterance gets its meaning as a result of its use in a specific situation. Hence, language games are not static, but continuously changing. Wickman (2006) suggests that the language of science could be approached as an example of a language game since students need to know how words are used in a particular activity in order to make meaning of science lessons.

\section{The Theory of Translanguaging}

Like Dewey (1934/1980) and Wittgenstein (1953/2012), García and Sylvan (2011) view language as an activity produced by social relations, rather than a simple system of structures giving us a set of skills. According to García (2009, 2011), bilingual students' language use and learning have been examined from a linear or monolingual perspective. Being bilingual has been regarded as having two different language repertoires, kept more or less apart (García 2009, 2011; García and Sylvan 2011). The difference between bilingual and monolingual students has been reduced to the fact that bilinguals speak an additional language. However, García (2009) argues that it is not possible to make a comparison between bilinguals' and monolinguals' language use in this way. She uses the concept translanguaging to describe the 'multiple discursive practices in which bilinguals engage in order to make sense of their bilingual worlds' (García 2009, p. 45). According to the theory of translanguaging, there are no clear boundaries between the languages of bilingual students. Instead, they are interrelated and intertwined in a dynamic way (García 2009, 2011). Bilinguals have 'one linguistic repertoire from which they select features strategically to communicate effectively' (García 2011, p. 1). Bilingual students' language use depends on their purpose for communication and the context in which the lessons are conducted. Generally, when an opportunity is given, bilinguals use both of their languages, and it is mostly in monolingual situations that bilinguals use only one of their languages (García 2009).

García $(2009,2011)$ states that several established terms in bilingual research, such as, mother tongue, first language and second language, are based on a monolingual view of bilingualism and 
not in line with the theory of translanguaging. Firstly, there are several different definitions of these terms within the bilingual field. Skutnabb-Kangas (1981) has, for example, shown that mother tongue may mean the language a person learns first, the most mastered language, the most used language, the language a bilingual identifies her/himself with or the language others identify a person with. Secondly, being bilingual does not always imply that one of the languages is introduced later in a person's life. Accordingly, it may not always be possible to categorise the languages of bilinguals as first and second language. One may for example ask how to draw a line between a person who has two mother tongues and a person who has a mother tongue and a second language. In this study, the term minority language in a society replaces terms such as first language, mother language and heritage language. Similarly, the term majority language in a society will be used instead of second language, additional language etc. (García 2009). Accordingly, for example, in Sweden, where data for this study derives from, we regard Swedish as majority language and other languages spoken by the population as minority languages.

\section{Analytic Approach}

Practical epistemological analysis (PEA) is based on the ideas of John Dewey, the later Ludwig Wittgenstein and sociocultural approaches (Wickman 2004, 2006; Wickman and Östman 2002). It is a well-established approach used to study meaning-making in science (Kelly et al. 2012). The unit of analysis is similar to sociocultural approaches; actions are analysed as situated in whole activities (see e.g. Harré and Gillett 1994; Wertsch 1995). In PEA, meaning-making is viewed as 'learning in action' (Wickman 2006, p. 52), implying that the process of meaning-making is studied as changes in students' actions.

PEA consists of four operational concepts: encounter, gap, relation and stand fast (Wickman and Östman 2002). An example to illustrate and explain how PEA is used is derived from the data collection for this study. The students were working with electrical circuits by using a battery, a battery holder, a lamp holder, a bulb and two wires. The teacher asked the students to connect the equipment and 'get the bulb to light up'. When the students were finished, the teacher moved around the groups, and the following conversation took place:

\begin{tabular}{ll}
\hline Teacher: & Hur har det gått här då? Fick ni det att lysa? \\
& How did it go here then? Were you able to get it to light up? \\
Meltem: & Ja. \\
& Yes. \\
Kenan: & Det gick jättebra. \\
& It went very well. \\
\hline
\end{tabular}

The term encounter refers to different meetings between individuals and between individuals and physical objects. In the example above, there was an encounter between the teacher and the students. In addition, since the teacher asked the students about an activity they had performed, there was also an encounter between students' earlier experiences and the on-going situation. In encounters, there are constantly occurring gaps. A gap concerns the need of making sense of what occurs. Hence, the teacher's questions 'how did it go here then' and 'were you able to get it to light up' implied a gap in the encounter. Gaps are filled by establishing relations to things standing fast. What stands fast is immediately understandable to the participants, and they can proceed with the activity without hesitations, questions or further explanations. Accordingly, the students' answers 'yes' and 'it went very well' firstly 
shows that the teacher's questions stood fast in the encounter. Secondly, they illustrate how the students filled the gap by construing a relation between the questions and their earlier experience of connecting the circuit. However, in some occasions, it is not possible for the participants to construe relations between the on-going situation and things standing fast. Then, the gap lingers and the activity stops or takes another direction. If the students had, for example, asked the teacher what he was aiming at when he said 'were you able to get it to light up' or what certain words, for example, 'light up' meant, we should say that the teacher's question did not stand fast in the encounter and resulting in a lingering gap (Wickman and Östman 2002; Wickman 2006). Filling gaps involves meaning-making and thus implies a reactualisation and transformation of earlier experiences. Accordingly, the process of meaning-making depends on gaps being noticed and filled. This is, in turn, a matter of whether or not words and other actions stand fast in the encounters. Additionally, gaps can be filled and make meaning to students although they may not take the direction the teacher intended. Furthermore, standing fast is temporal, meaning that what stands fast in one situation may later be questioned by the same individuals (Wickman and Östman 2002; Wickman 2006).

In the present study, bilingual students' encounters with their teacher, peers and the content of the science lessons are examined. We analyse how students construe relations between the on-going situations and their earlier experiences, expressed in their majority and minority language (as defined above). A main concern for this study is how different situations in a multilingual class enable students to use their whole language repertoire and what this means for their meaning-making in science. According to Wickman (2004, p. 327) practical epistemologies are 'descriptions of people's ways of meaning making in action'. Consequently, we argue in line with Wickman and Östman's (2002) reasoning that analysing what students do and say in particular activities by using PEA enables us to examine the consequences of students' language use for their meaning-making in science.

\section{Methods}

The data collection of this study consists of observations in a multilingual class, located in a suburban area in Sweden. Before further describing how data were collected, we will contextualise the study by giving a picture of how education for bilingual students is conducted in Sweden and the achievements of bilingual students.

\section{Bilingual Students in Sweden}

Education in Sweden is in general conducted monolingually in Swedish, which is the official language of the country. Bilingual students are offered 'mother tongue instruction', often scheduled after the ordinary school day. However, students are required to use their 'mother tongues' at home to be entitled to this course. An investigation made by the Swedish National Agency for Education (2008) shows that bilingual students who attend mother tongue instruction finish lower secondary school with higher grades in comparison with bilingual students who choose not to take the course. Furthermore, schools may offer extra support in students' minority languages. It is the principal's responsibility to determine if a student needs this support and how it then should be conducted. Since few schools make use of this opportunity, it is not possible to make general conclusions regarding the effect of the support. In addition, some bilingual students are offered lessons in "Swedish as 
a second language' instead of 'Swedish'. Again, the principal decides which course bilingual students should attend. The decision is based on test results, and consultation with teachers and parents. Generally, students who have attended this course finish lower secondary school with the lowest grades in comparison to students taking the course 'Swedish' (The Swedish National Agency for Education 2008). According to the Swedish National Agency for Education (2008), it is not possible to make any conclusions concerning the relation between the students' achievements and the course 'Swedish as a second language'. First, students attending the course are on average from families with low socioeconomic status. Secondly, many schools are not following the directions to give the course: for example, although the course is a subject on its own, many schools interpret it as additional resulting in students attending both 'Swedish' and 'Swedish as a second language' (The Swedish National Agency for Education 2008).

All students in compulsory school perform standardised national tests in Swedish or 'Swedish as a second language' in grades 3,6 and 9. Concerning science education, standardised national tests in biology, physics and chemistry are performed in grade 9 , the last year of compulsory school. In general, bilingual students attending 'Swedish as a second language' receive lower grades than their peers in 'Swedish' (The Swedish National Agency for Education 2016b), and are overrepresented in the group not passing the tests both in Swedish and in science (The Swedish National Agency for Education 2016c, d). There is also a positive correlation between numbers of years spent in Sweden and bilingual students' achievements on these tests (The Swedish National Agency for Education 2016b, c, d).

\section{The Study Design and Procedure}

The class consisted of 31 students, aged 9-10 years (3rd grade). All the students were bilingual, and several minority languages were represented in the class, for example, Arabic, Somali, Turkish and Russian. The teacher was monolingual in Swedish and did not speak any of these minority languages. Since the first author is bilingual in Swedish and Turkish, the study focused on four students, Deniz, Evin, Kenan and Meltem, who all spoke Turkish. By doing so, the data could be analysed without the need for interpreters. The four students were born and raised in Sweden, but teacher stated that all had failed on internal language tests in the 3rd grade and that they did not yet have fully developed language skills in Swedish.

The science content in the observed lessons was electricity, and the teaching switched between whole class instructions and hands-on activities in small groups. The lessons were performed by following the Swedish version of Science and Technology for Children (STC), which is a wellestablished program developed in the USA to support younger students' learning in science. It consists of different units, for example, electricity, water and sustainable development. The program is planned around different hands-on activities and includes teacher guides, worksheets for the students and boxes with practical equipment (NTA - Naturvetenskap och Teknik för Alla 2016). In total, eight science lessons were documented by audio and video recordings during a period of 6 weeks, which resulted in approximately $20 \mathrm{~h}$ of data. To facilitate correct interpretation of the data collection, the first author was present in the classroom during the recordings, observing students' actions at large and taking notes of what occurred. The recordings have been transcribed and analysed in accordance with the study questions. Firstly, the data was divided regarding students' translanguaging possibilities. Since class instruction was conducted in Swedish and the students used both their languages during the hands-on activities, two main categories were discernable: students' conversations with the teacher and students' conversations with each 
other. Secondly, to examine the relation between students' language use and meaning-making further, analysis was made by using PEA and the theory of translanguaging. Finally, 1-2 excerpts from each category were chosen. The excerpts are illustrative, meaning that they are selected to exemplify the findings of the study. They start with the original utterances; Swedish is written with no emphasis and Turkish with bold letters. This is followed by an English translation, written in italics. The linguistic incorrectness in the translations corresponds to the students' ways of expressing themselves in Swedish. The initial coding and analysis was made by the first author and then checked by the other authors. Both the coding and the analysis were revised until an agreement was reached. The study is conducted in accordance with the ethical considerations stated by the Swedish Research Council (see The Swedish Research Council 2016).

\section{Results}

Since the class was multilingual, whole class instructions could only be given in Swedish. The conversations took place between the teacher and the students, and rarely between students. During hands-on activities, the four students in focus worked together and used both of their languages. They predominantly spoke with each other and seldom with other classmates. The students were also involved in some talk with the teacher during the hands-on activities. Accordingly, students' translanguaging possibilities differed depending on with whom they spoke. Under the headings that follow, we start by showing students' conversations with the teacher during whole class instruction, and then continue with group activities and students' conversations with each other. We examine how students used their languages and what consequences this had for their meaning-making in science.

\section{Students' Conversations with the Teacher}

Students' conversations with the teacher were conducted in two different ways. In some situations, the talk was characterised by a typical initiation, response and evaluation (IRE) pattern (Bellack, et al. 1966). In other situations, the students made longer utterances and were involved in argumentation, discussions, explanations and generalisations. Hence, the category students conversations with the teacher' was further divided into two subcategories: IRE in majority language and longer conversations in majority language. In general, a conversation characterised by an IRE pattern took less than $1 \mathrm{~min}$, whereas longer conversations proceeded during several minutes, approximately 3-8 $\mathrm{min}$. When the two ways of conducting conversations were compared with each other, a general pattern was discernable, that is, students' language limitations were related to the character of the conversation in which they were engaged. Table 1 illustrates students' language limitations during conversations with the teacher according to

Table 1 Students' conversations with the teacher

\begin{tabular}{|c|c|c|c|c|}
\hline \multirow{2}{*}{$\begin{array}{l}\text { Conversation } \\
\text { type }\end{array}$} & \multicolumn{2}{|l|}{ IRE } & \multicolumn{2}{|c|}{ Longer conversations } \\
\hline & $\begin{array}{l}\text { No language } \\
\text { limitations }\end{array}$ & $\begin{array}{l}\text { Language } \\
\text { limitations }\end{array}$ & $\begin{array}{l}\text { No language } \\
\text { limitations }\end{array}$ & $\begin{array}{l}\text { Language } \\
\text { limitations }\end{array}$ \\
\hline Number & 99 & 4 & 2 & 10 \\
\hline Percentage & 96.1 & 3.9 & 16.7 & 83.3 \\
\hline
\end{tabular}


conversation type. During the eight observed lessons, 103 conversations with an IRE pattern and 12 longer conversations were conducted between the teacher and the students in whole class. In $96.1 \%$ of the conversations with an IRE pattern, the students' meaning-making proceeded without any visible language limitations. However, when the students made a longer utterance, the result was different. In about $83 \%$ of the longer conversations, the students' language repertoire limited their possibilities to participate in the activities and make meaning of the activities.

\section{IRE in Majority Language}

We will first illustrate a situation where the teacher followed an IRE pattern. The conversation took place during whole class instruction. The purpose of the lesson was learning how to connect an electrical circuit by using a battery, a battery holder, a bulb, a lamp holder and two wires. Moreover, an overall purpose of the project concerned writing reports about the hands-on activities. This lesson was conducted in an early stage of the unit, and the students found it to be difficult to write a report on their own. Hence, the teacher asked the students to retell the activity and wrote their answers on the whiteboard. Then, the students copied the text into their notebooks. After the students had connected the electrical circuit, the teacher told them to put the equipment back in its box. Therefore, the students could not point at the equipment or show the teacher how the connection was made. Instead, they had to talk about the activity by actually naming the different parts. The teacher asked questions about each step of the activity, which were answered by the students and then evaluated and written on the whiteboard by the teacher:

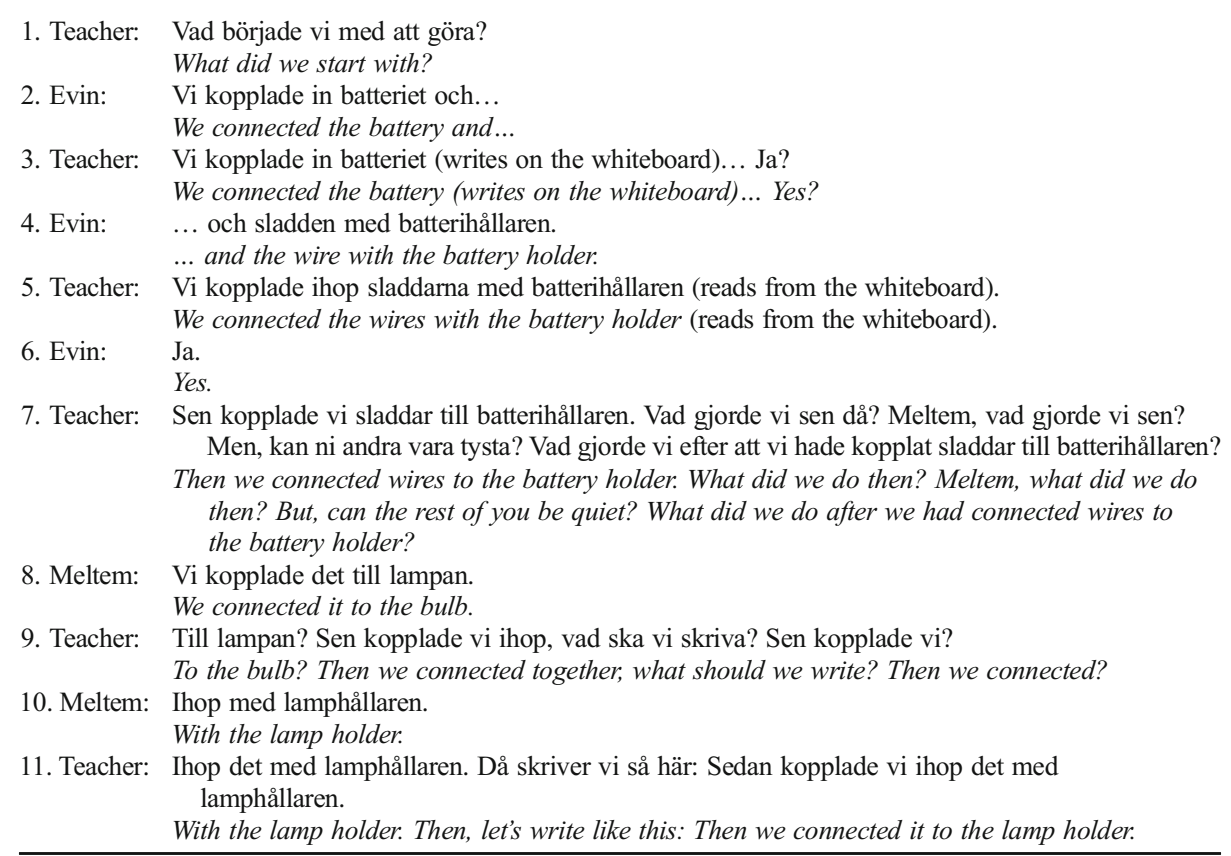

A gap occurred with the teacher's question (1), which was immediately filled when Evin construed the relation 'we connected the battery and... the wire with the battery holder' ( 2 and 
4). The teacher wrote Evin's answer on the whiteboard, implying that her answer stood fast in the encounter between the teacher and the student (5). Hence, Evin's earlier experience of making the connection was reactualised and transformed, meaning that she was able to retell the activity and make meaning in the new situation without having the equipment at hand. The teacher then continued by asking Meltem to tell how the activity had proceeded (7). Meltem answered by construing the relation 'we connected it to the bulb' (8). The teacher questioned Meltem's answer by saying 'to the bulb?' and then asked her once again about the second step of the procedure (9). Accordingly, Meltem's answer did not stand fast in the encounter between her and the teacher. A reasonable explanation for the teacher's questioning (9) may be that the wires were connected to the lamp holder, not the bulb, as Meltem then suggested (8). Meltem had changed her answer and used the word 'lamp holder' instead (10). Her answer stood fast this time, as the teacher repeated it and wrote it on the whiteboard (11). Like Evin, Meltem's earlier experience of connecting the circuit was reactualised and transformed, implying that she had also made meaning of the situation.

The example above involves two IRE conversations (1-7 and 7-11). The teacher asked the students to retell the hands-on activity she herself had instructed. Hence, the answers to the questions ( 1 and 7 ) were predetermined and could be answered with short descriptions. The needed words, for example, bulb, battery, battery holder and lamp holder, had all been introduced and worked with not only during this activity, but also in earlier lessons. Although the students' possibilities to translanguage were highly limited since the teacher only spoke Swedish, both the teacher's questions and the students' answers stood fast in the encounters (1-7 and 7-11). It is unclear if the students had learned how to connect a closed electrical circuit since the teacher's questions could be answered with fragmented answers. Despite this, the example shows that the students made meaning of the activity and were able to participate without any language limitations.

\section{Longer Conversations in Majority Language}

In the example chosen to illustrate conversations where students needed more advanced language mastery, the students were once again working with electrical circuits. The main purpose of the lesson was learning how to connect an electrical circuit by using a battery, a bulb and only one wire. In addition, the activity implied making predictions, explaining, discussing and arguing for one's own ideas. The teacher gave each student a box with the needed equipment and a worksheet with pictures showing different connections (Fig. 1). She asked the students to think about whether or not the bulb would light up when the equipment was connected as shown on the pictures and share their ideas with their group members. If they thought that the bulb would light up, they were supposed to write 'on'; if not, 'off' over each picture. The teacher also told the students to try agreeing on one answer for each picture. Thereafter, the students continued by connecting the equipment as shown on the pictures and wrote their results, that is, 'on' or 'off' under the pictures (Fig. 1). The lesson ended with a whole class discussion concerning the results of the activities. Before starting the discussion, the teacher asked the students to put the equipment back in the boxes since she wanted them to discuss the connections without having the equipment at hand. When they talked about the third picture from the top left (Fig. 1) where according to the answer key, the bulb should light up, the groups' answers differed from each other. Some groups said that the bulb did light up, while others claimed the opposite. The students 
suggested reasons for the differing results. Kenan's group had succeeded in lighting the bulb, and he had an idea about why some of the other groups' efforts did not work:

$\begin{array}{ll}\text { 12. Teacher: } & \text { Får jag höra! } \\ \text { Let me hear! } & \text { För att... för att, um... det står där att man ska stoppa under den ... inte ... här } \\ \text { 13. Kenan: } & \text { (points to the side of his legs) ... inte på benen. } \\ & \text { Cause ... cause, um ...it says that you have to put it under it ... not .... here } \\ & \text { (points to the side of his leg) ... not on the legs. } \\ & \text { Så här ... (tries to open the box with the bulb to show the teacher, but fails). } \\ & \text { Like this ... (tries to open the box with the bulb to show the teacher, but fails). } \\ \text { 14. Deniz: } & \text { Du får berätta hur du menar (goes to the student with a bulb). } \\ & \text { Tell us what you mean (goes to the student with a bulb). } \\ \text { 15. Teacher: } & \text { Den skulle röra hit, (points to the side of the socket) inte dit, } \\ & \text { (points under the socket) den funkar inte för att. } \\ \text { 16. Kenan: } & \text { It should touch here, (points to the side of the socket) not there, } \\ & \text { (points under the socket) it doesn't work because. } \\ & \text { Ok, så du menar att om jag hade satt sladden mot där } \\ \text { (points to the side of the socket), skulle den funka? } & \text { Ok, so you mean that if I had put the wire touching there } \\ \text { 17. Teacher: } & \text { (points to the side of the socket), it would work? } \\ & \text { Exakt! } \\ \text { Exactly! } & \text { Ok... }\end{array}$

Kenan started by telling how the wire and the bulb were supposed to be connected according to the worksheet by construing the relation 'put it (the wire) under it (the socket)' to a lighting bulb. However, he did not find the words needed for further explaining what he meant. This was observable by the hesitations and the pauses he made. Kenan said 'not... here' and simultaneously pointed to the side of his legs. After hesitating for a while, Kenan also used the word 'leg' when talking about the socket of the bulb. Accordingly, Kenan construed a relation between his own legs and the socket of the bulb when describing where on the socket the wires were not supposed to be connected (13). Consequently, it is reasonable to assume that the Swedish word 'socket' was not a part of his language repertoire. Kenan's explanation was immediately understandable to Deniz, who had worked with him during the investigation. Deniz tried to open the box with the equipment to show what Kenan meant, but somehow she did not manage to open the cover (14). The teacher seemed aware of Kenan's dilemma as she brought a bulb and told Kenan to show her what he meant (15). With a real bulb, Kenan construed the relations 'touch here' to the side of the socket and 'not here' to the underside of the socket, simultaneously pointing to the different parts of the socket (16). The teacher repeated the statements Kenan had made (17), and Kenan responded by confirming her (18 and 20).

When comparing this example (12-21) to the previous one (1-11), we can see some similarities. Both conversations took place during a whole class instruction conducted in Swedish. However, the latter situation (12-21) required that Kenan made a longer utterance and concerned a word (socket) that had not been introduced during the unit. Moreover, since the answer to the question about the differing results was not predetermined as in the first example (1-11), the teacher did not control the situation in the same way. Consequently, this conversation (12-21) required more 
advanced language mastery in Swedish. Kenan believed that the reason some of his classmates did not succeed lighting up the bulb was that they connected the wire under the socket instead of at the side of it (13 and 16). However, his language proficiency in Swedish limited his possibilities to express this. Kenan's idea was not intelligible to the teacher until he showed what he meant by pointing at a bulb (16-18). It is not possible to determine whether or not the word 'socket' was a part of his language repertoire in Turkish. Even if not, the student would probably have a greater chance to explain his idea if he had gotten the opportunity to use his whole language repertoire. Accordingly, in this situation, Kenan's earlier experiences of making the connection shown on the third picture from the top left (Fig. 1) were reactualised and transformed. Since verbal language was not enough to fill the gaps, other resources were needed to make meaning of the situation. In addition, the example illustrates the importance of practical equipment during science lessons, especially in multilingual classrooms.

The previous example (12-21) illustrated how the students' language repertoire limited their possibilities to make meaning of the science content during whole class instructions requiring longer utterances. Verbal language was not enough and Kenan used practical equipment to express himself. Occasionally, the students also used their minority language in whole class, although in a limited way, when their language proficiency in Swedish limited their possibilities to express their ideas. The following example is from a lesson aiming at learning about the discovery of electricity, a request from the students themselves. In a previous lesson, the teacher had asked the students what they wanted to know about electricity and then wrote their questions and thoughts on a flipchart. The teacher started the current lesson by reminding the students about their requests:

22. Teacher: $\quad \ldots$ ehh... och saker som ni ville veta om elektriciteten, hur uppfanns elektriciteten (reads from the flipchart)...

... ehh ... and things that you wanted to know about electricity, how was electricity discovered (reads from the flipchart) ...

23. Kenan: Jag vet!

I know!

24. Teacher: Ok, var så god.

Ok, go ahead.

25. Kenan: Det var så där en kille ... jag kommer inte ihåg vad han hette, jag såg det på tv, men han hade en burk och han hade en drake med någon... ehh... (illustrates by waving with his hands) ... någon rep eller något, han hade ehh... Han hade knutit ihop eller något på inne flaskan eller något. Ja, sen när det kom sådär blixt på draken, från, från repen det kom sådär inuti burken. Han fångade ... han făngade ... elektriken.

It was like that a guy ... I don't remember what his name was, I saw it on TV, but he had a jar and he had a kite with something ... eh ... (illustrates by waving with his hands) ... some rope or something, he had ehh ... He had sort of tied together on inside the bottle or something. Yes, then when it sort of came lightning on the kite, from, from the rope, it sort of came inside the jar. He caught ... he caught ... the electricity ${ }^{1}$.

26. Teacher: Elektriciteten.

The electricity.

27. Kenan: Ja.

Yes.

28. Teacher: Ja, det var sen, men det här var faktiskt det allra första som har med elektriciteten att göra som vi vet. Det där är om du prata om ... jag tror att det hände någon gång på 1700-talet. Men det här ... det fanns en man i Tyskland som hette Otto von Guericke ...

Yes, that was later, but this was in fact the very first thing that has to do with electricity that we know of. The thing you talked about ... I think it happened sometime in the eighteenth century. But this ... there was a man in Germany called Otto von Guericke ... 
Fig. 1 The worksheet with the electrical connections the students discussed
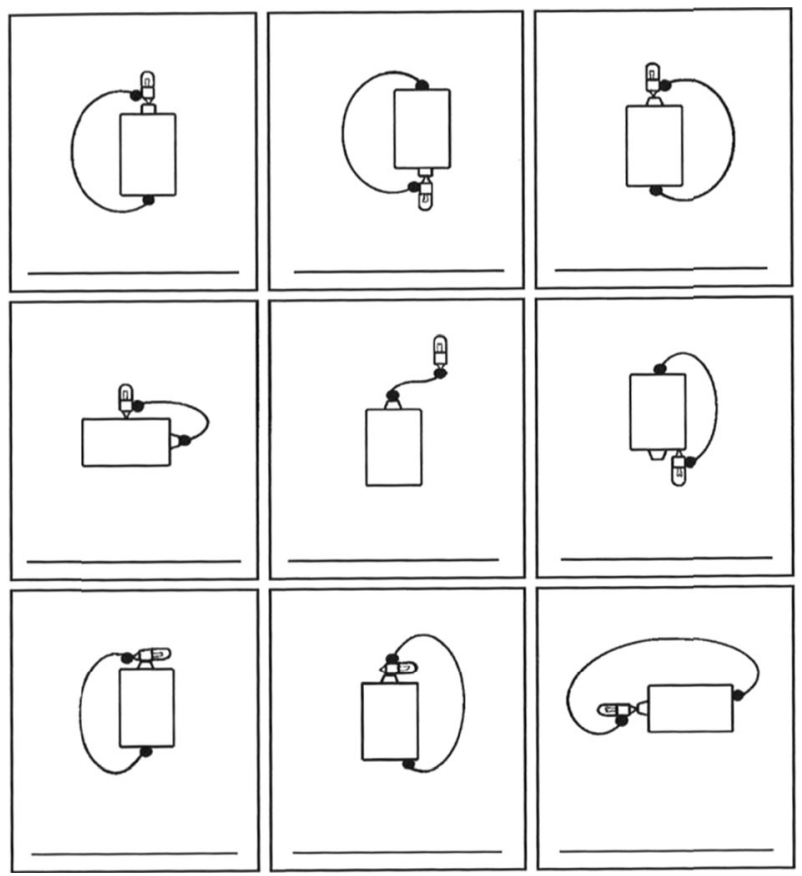

${ }^{1}$ Electricity' in Turkish is 'elektrik' and 'elektricitet' in Swedish. 'The electricity' is 'elektriği' in Turkish and 'elektriciteten' in Swedish

The teacher had just started to introduce the content of the lesson when she got interrupted by Kenan claiming that he knew how electricity was discovered (22-23). He had watched a TV program concerning the discovery of electricity and construed a relation between the program and the current activity. Kenan started to retell the program by saying that a 'guy... had a jar and a kite with something', but then there was a break in his utterance and he started to hesitate. He waved his hands to illustrate what this 'something' was. After a couple of seconds, Kenan said that it was a rope. Then, he said 'he had' to proceed with his retelling, but hesitated again. He continued after a couple of seconds by saying 'he had sort of tied together on inside the bottle or something', probably to describe how the person on the TV program had tied a 'bottle' to the 'rope' of the kite. Finally it had 'came lightning on the rope', which 'sort of came inside the jar'. Then, Kenan intended to talk about what the person had 'caught', but hesitated and there were once again breaks in his utterance. At last, Kenan solved the situation by using the Turkish word for electricity, 'elektrik', but added a Swedish suffix, '-en' ('the' in English) (25). Since the Turkish word for 'electricity' is quite similar to the Swedish word, Kenan's utterance (25) was fully understandable to the teacher. She corrected him by saying the Swedish word (26), which Kenan confirmed (27).

Obviously, Kenan had learnt about the experiment Benjamin Franklin performed in 1752 from a TV program. In this situation, he construed a relation between this earlier experience and the content of the lesson, that is, the discovery of electricity. In other words, the student's earlier experiences concerning the TV program were reactualised and transformed as he made meaning of the current activity. However, considering the breaks and hesitations in his utterances, Kenan's language proficiency once again limited his possibilities to express himself (22-27). The difference between this situation (22-27) and the previous one (12-21) was how the last gap 
concerning what the person from the TV program had 'caught' was filled. Despite the fact that the Swedish word for electricity (elektricitet) had been used both during the current lesson (22) and in earlier ones, Kenan had difficulties in remembering how to say it in Swedish. Since the word was necessary for Kenan to finish his utterance, he solved the situation by using the Turkish word 'elektrik' (25). However, as stated before, situations in which students used Turkish as a resource when participating in whole class talk was exceptional as the students' possibilities to translanguage were minimal. Instead, the conversations were conducted monolingually in Swedish.

\section{Students' Conversations with Each Other}

During hands-on activities, students with the same minority language worked together, and translanguaging was constantly present in their meaning-making process. A general pattern was that scientific terms, for example, connect, battery holder and wire, were predominantly in Swedish, whereas everyday words were expressed in both languages. Furthermore, the character of the hands-on activities required the students to involve in longer conversations by arguing, discussing, explaining and generalising. Table 2 shows students' language limitations during conversations with each other. In $90 \%$ of the eight observed lessons, the students' conversations continued without any visible language limitations. In comparison, the number was $16.7 \%$ in conversations with the teacher (Table 1). It should be emphasised that the students during these situations did not only have the possibility to use both their languages but also practical equipment. However, the students' possibility to use both their languages did not mean that all conversations proceeded without language limitations. Although the conversations among the students were carried out bilingually, the teacher's instructions, both oral and written, were only in Swedish. In $10 \%$ of the activities, some of the words the students needed to use when proceeding with the activities were not a part of their language repertoire (Table 2). It should be added that students' conversations with each other (Table 2) were in general longer than their conversations with the teacher (Table 1). It was not uncommon that one conversation continued during the whole hands-on activity.

\section{Using Both Languages Without Limitations}

In this section, we start by illustrating bilingual students' translanguaging without any visible language limitations during hands-on activities. Then, we will continue with an example aimed at showing that all words may not stand fast in the encounters, although bilingual students have the possibility to use their whole language repertoire and practical equipment. Both examples are from the same lesson. The overall purpose was learning how to connect an open electrical circuit and develop knowledge about the fact that metals conduct electricity while other materials, for example, plastics and wood, do not. Another purpose of the lesson was continuing to work with arguing,

Table 2 Students' conversations with each other

\begin{tabular}{llc}
\hline & No language limitations & Language limitations \\
\hline Number & 18 & 2 \\
Percentage & 90.0 & 10.0 \\
\hline
\end{tabular}


discussing, explaining and generalising by making predictions and talking about the results of the investigations. Deniz, Evin and Meltem worked together. Each group was provided with a box including a battery holder, a battery, a lamp holder, a bulb and three wires. The teacher started the lesson by giving instructions about how to connect an open electrical circuit:

29. Teacher: . . för ni ska nämligen koppla ihop det här nu i en krets ... ok, förstår ni? ... Jag visa er den koppling ni ska göra ... (holds up a picture of the connection). Nå har alla fått en tredje ... sladd?

... 'cause you will connect this in a circuit now ... ok, do you understand? I'll show you the connection you will make ... (holds up a picture of the connection). Well, has everyone got a third wire?

30. Students: Ja.

Yes.

31. Teacher: Här (points to the picture in the book), ni har en batterihållare, ni har en lamphållare. Ni ska använda en i varje grupp. En sladd ska sitta i den änden (points to the battery holder). Kom ihåg metall mot metall och de (points to the unattached ends of the wires) ska hänga löst. Det är viktigt. Koppla! Ta en låda, en persons låda och ställ den mellan er.

Here (points to the picture in the book), you've got a battery holder, you've got a lamp holder. You will use one in every group. One wire will be on this end (points to the battery holder). Remember, metal to metal and these (points to the unattached ends of the wires) will hang loose. That's important. Connect! Take a box, a person's box and put it between you.

32. Deniz and (start taking out the equipment from the box)

Evin

33. Deniz:

34. Meltem:

35. Evin:

36. Meltem:

37. Evin:

38. Deniz:

39: Meltem:

40. Deniz:

41. Meltem:

42: Deniz:

43. Evin:

44. Deniz:

45. Evin:

46. Meltem:

47: Deniz:

48: Evin:

\section{Men Meltem! Dıșında durma, sen de bir șeyler yap}

But Meltem! Don't just sit there, do something!

\section{Sanki bize bir șeyler bıraktınız da.}

Like if you left something for me.

Meltem, sen șunu (wire) buraya (battery holder) koppla yapacaksın, sen (Deniz) şunu (wire) oraya (lamp holder) koppla yapacaksın.

Meltem, you are supposed to connect this (wire) here (battery holder), you (Deniz) are supposed to connect this (wire) over here (lamp holder).

Sabahtan beri koppla, koppla (with an irritated/angry tone).

Ever since the morning, connect, connect (with an irritated/angry tone).

(Connects a closed circuit by using only two wires).

Nej, en ska bli lös

No, one will be loose

Ja.

Yes.

Burası (points at one of the wires that are supposed to be unattached) ska bli lös. Yan(i) ... ver (takes the equipment from Evin)!

Her (points at the wires that are supposed to be unattached) will be loose. So ... give it to me (takes the equipment from Evin)!

Gözümün içine sokuyordun!

You were putting it in my eye!

Meltem lägg av! (Connects an open circuit by using all three wires).

Meltem, stop it! (Connects an open circuit by using all three wires).

Inte så!

Not like that!

Jo, men kolla, bak metallen...

Yes, but look, look, the metal...

Får jag se, får jag se (takes the equipment).

Let me look, let me look (takes the equipment).

$$
\text { Allah, Allah! }
$$

Oh my God!

Kızım versene!

Give it to me girl!

Så, bir dakika (connects the unattached ends of the wires to each other. The bulb starts to light up). Ååå, det går! Vi kunde! 
So, one minute (connects the unattached ends of the wires to each other. The bulb starts to light up). Oh, it works! We did it!

49. Teacher:

Bra, ni fick till och med det att lysa! Bra jobbat!

Good, you even got it to light up! Well done!

The teacher told the students what to do by saying 'connect this in a circuit' (29). She continued by pointing at a picture in a textbook showing the circuit the students were supposed to connect and naming the different parts of the equipment. Thereafter, the teacher pointed at the battery holder and showed where one of the wires should be connected. She also construed the relations 'metal to metal' and that the unattached ends of the wires should 'hang loose' to the circuit (31). Deniz and Evin started by taking out the equipment from the box (32), and Deniz noticed that Meltem was not participating in the activity. She asked Meltem to join (33), but Meltem answered by saying that the other two girls, Deniz and Evin, were already doing everything by themselves (34). Evin then told Meltem what to do by construing a relation between 'connect', 'this (wire)' and 'here (battery holder)'. Then, she said 'connect this (wire) over here (lamp holder)' to Deniz (35). However, Deniz and Meltem did not do what Evin what she asked them to. Instead, Meltem used a Turkish expression and complained that they had to connect electrical circuits all the time (36), and Evin started to connect the equipment herself. However, she used only two wires and was connecting a closed circuit as they had done during earlier lessons (37).

Apparently, Evin had construed a relation between her earlier experiences of connecting closed electrical circuits and the current activity in making meaning of the situation. Evin's actions (37) did not stand fast in the encounter between the students since Deniz questioned her by saying 'no, one will be loose' (38), which Meltem supported (39). Evin ignored the other students and continued to connect the equipment in a closed circuit. Deniz now pointed at the part of the circuit that was supposed to be unattached and repeated her idea. She once again used the same word, 'loose', like the teacher (31) to describe how the connection was supposed to be made (40). Evin was still ignoring Deniz who reacted by taking the equipment from Evin and connecting an open electrical circuit (40 and 42). In doing so, Deniz's earlier experiences of connecting closed circuits were reactualised and transformed in the current activity since she also learned how to connect open circuits. However, Evin did not agree with Deniz (43). Deniz started to explain the connection she had made to Evin (44), but she could not finish since Evin took back the equipment from her (45). Evin connected the unattached ends of the wires to each other and construed a closed circuit. The bulb started to light up and Evin expressed her satisfaction by saying 'Oh, it works! We did it!' (48). This confirms that the purpose of the activity, according to Evin, was to connect a closed electrical circuit and make the bulb to light up. The teacher, who had not been present during the students' discussion about if the circuit should be closed or open overheard Evin's utterance (48) and reacted positively to how Evin had connected the wires (49). Later, the teacher asked all the groups to do the same and to check if they had connected the equipment correctly.

Accordingly, it is possible to include both languages of bilingual students in science class, although the teacher is monolingual and the class is multilingual. By letting students with the same minority language work together, the teacher enabled them to use their whole language repertoire. When this opportunity was given, the students used both their languages as resources when construing relations and making meaning of the science content. The gaps were not immediately filled in this situation either (29-49, cf. 12-21 and 22-28). However, it was not the meaning of words that did not stand fast but rather how the activity 
was supposed to be performed (35-48). It is not possible to determine why Evin misinterpreted the teacher's instructions and if this was related to her language proficiency in Swedish or the teacher's explanation. During whole class instruction, the teacher had only explained how one of the three wires should be connected and then pointed on a picture of the connection.

\section{Using Both Languages with Limitations}

The lesson also aimed at learning that metals conduct electricity while some other materials do not. When all groups had connected an open electrical circuit (29-49), the teacher gave them a little bag with different objects. She drew a table on the whiteboard and asked the students to do the same in their notebooks. The table consisted of three columns. The teacher wrote 'objects' in the first column, 'predictions' in the second and 'results' in the last one. Then, she divided the second and the third columns into two and wrote 'does light up' and 'does not light up'. She continued by holding up the objects in the bag, one by one, named them and wrote the terms in the first column of the table. She asked the students to do the same, make predictions about whether or not the bulb would light up when the objects were connected to the circuit and then mark their prediction in the table. Lastly, she asked the students to test if the objects conducted electricity:

\begin{tabular}{|c|c|}
\hline 50. Meltem: & $\begin{array}{l}\text { Şundan (tee peg) basslayalım. } \\
\text { Let's start with this one (tee peg). }\end{array}$ \\
\hline 51. Evin: & (Still filling in the table in her notebook) \\
\hline $\begin{array}{l}\text { 52. Deniz and } \\
\text { Meltem: }\end{array}$ & (Connecting the tee peg to the equipment). \\
\hline \multirow[t]{2}{*}{ 53. Meltem: } & Lyser inte, ja (happily)! \\
\hline & Doesn't light, yes (happily)! \\
\hline $\begin{array}{l}\text { 54. Deniz and } \\
\text { Meltem: }\end{array}$ & (Mark the column 'does not light up' in their notebooks). \\
\hline \multirow[t]{2}{*}{ 55. Evin: } & Golfpeg (reads from her notebook) vad är golfpeg? \\
\hline & Tee peg (reads from her notebook) what's tee peg? \\
\hline \multirow[t]{2}{*}{ 56. Deniz: } & Yaptık ya onu, iște șu (shows her the tee peg). \\
\hline & We have done it, here, this one (shows her the tee peg). \\
\hline \multirow[t]{2}{*}{ 57. Evin: } & Hayır o golf (points at a straw) aha sugrör. \\
\hline & No, that's the tee (points at the straw) oho straw. \\
\hline 58. Deniz: & $\begin{array}{l}\text { Där (points at her notebook to show Evin that she has marked 'does not light'). } \\
\text { There (points at her notebook to show Evin that she has marked 'does not light'). }\end{array}$ \\
\hline 59. Evin: & $\begin{array}{l}\text { (Copies Deniz's answer) ... Ya bu }{ }^{1} \text { ne de (points in her notebook where it is written 'wire nail')? } \\
\text { (Copies Deniz's answer) ... But, what's that (points in her notebook where it is written } \\
\text { 'wire nail')? }\end{array}$ \\
\hline \multirow[t]{2}{*}{ 60. Meltem: } & O ne? \\
\hline & What's that? \\
\hline \multirow[t]{2}{*}{ 61: Deniz: } & $\begin{array}{l}\text { Trådspik (reads in her notebook), hangisi trådspik? Fröken! Fröken, kan du komma? Vilken } \\
\text { är kopparspik, jag menar trådspik? }\end{array}$ \\
\hline & $\begin{array}{l}\text { Wire nail (reads in her notebook), which one is the wire nail? Miss! Miss, can you come? } \\
\text { Which one is the copper nail, I mean the wire nail? }\end{array}$ \\
\hline \multirow[t]{2}{*}{ 62. Teacher: } & Koppartråd? Här är koppartråden (points). Lägg tillbaka allting i påsen. \\
\hline & Copper wire? Here is the copper wire (points). Put everything back in the bag. \\
\hline \multirow[t]{2}{*}{ 63. Deniz: } & Trădspik? \\
\hline & Wire nail? \\
\hline \multirow[t]{2}{*}{ 64. Teacher: } & $\begin{array}{l}\text { Trådspiken var den längsta, smalaste, där är den (points at a wire nail made of steel). Glöm } \\
\text { inte lägga tillbaka sakerna så att ni inte tappar dem. }\end{array}$ \\
\hline & $\begin{array}{l}\text { The wire nail is the longest, the thinnest, there it is (points at a wire nail made of steel). } \\
\text { Don't forget to put back the things so that you don't accidently drop them. }\end{array}$ \\
\hline
\end{tabular}


After making the predictions, Deniz and Meltem started by testing if the first object on the table, a tee peg, ${ }^{1}$ conducted electricity. The students connected the tee peg to the electrical circuit and observed that the bulb did not light up. The result was in coherence with Meltem's prediction, and she expressed her satisfaction by saying 'does not light up, yes!' (52-53). Evin had been busy filling in the table in her notebook (51). When she was finished, she read the name of the first object they were supposed to test. However, the word 'tee peg' was not part of her language repertoire, and she asked the other students what it meant (55). Deniz told Evin that they already had tested it and showed her the object by construing a relation between the words 'tee peg' in her notebook and an actual tee peg by pointing at it (56). However, the relation Deniz construed did not fill the gap as Evin questioned it. Then, Evin started to construe a relation between the word 'tee peg' and a straw, which was one of the other objects they were supposed to test, but she did not finish her sentence since she remembered that the object she was pointing at was a straw (57). Deniz pointed at the result in her notebook (58) and Evin copied her answer (59). The students continued and read that the second object to test was a wire nail. ${ }^{2}$ They asked each other what 'wire nail' meant (59-61). Accordingly, the word did not stand fast in the encounter between the students, the objects and their written names in the notebooks. Since neither of them could answer the question, the gap still lingered and Deniz called for the teacher. In doing so, she mixed up the words 'wire nail' with the third object on the list, 'copper wire' (61). The teacher answered by construing a relation between Deniz's question and the copper wire by pointing at it (62). Deniz asked her once again about the wire nail (63), which the teacher then pointed out (64).

Before conducting the hands-on activity, the teacher asked the students to discuss whether or not they thought the different objects would conduct electricity when connected to the circuit. This never occurred; instead, the students marked their answers individually and in silence. The teacher looked in their notebooks to make sure they had marked their predictions in the table, which they all had. However, in the encounter between the actual objects and the students, that is, when they actually tested if the objects conducted electricity, it appeared that the words did not stand fast (55-64). Hence, one may ask how they could mark their predictions in the table. They probably had randomly marked an option in cases the name of the object was not part of their language repertoire. However, the words in the table needed to be related to the real objects in order to conduct the hands-on activity. Hence, the main focus during the activity turned out to be naming the objects and the students never discussed the results when they connected the objects to the electrical circuit. Accordingly, it is reasonable to assume that focusing on the names of the objects became the main purpose of the activity at the expense of the science content, which was learning if different materials conduct electricity or not.

\section{Discussion}

The results of this study highlight several circumstances that have impacts on bilingual students' meaning-making in multilingual science classes. The classroom interactions varied as a result of the different forms of instruction. In whole class situations, with a teacher monolingual in the majority language and students bilingual in a range of minority languages, the dialogue left little room for translanguaging and use of minority languages (lines 1-11 and

\footnotetext{
${ }^{1}$ A tee peg is used when playing golf. It is pushed down in the teeing ground, and the golf ball is then placed on it. It is made of plastic or wood; the one the students used in the hands-on activity was made of wood.

${ }^{2}$ A wire nail is a long and thin nail made of steel wire.
} 
12-21). As the classroom activity switched to work in smaller groups where students shared the same minority language, a dramatic change of language use, including both Turkish and Swedish, was observed (lines 29-49). A question then is, do the different situations contribute to scientific meaning-making and, in that case, how?

The whole class instruction was dominated by an IRE pattern. In such situations, the students were able to present correct, but short responses and proceed with the activities (lines 1-11). Questions like 'what did we start with' (line 1) did not require advanced language mastery and was answered with simple and short phrases, like 'we connected the battery ... and the wire with the battery holder' (lines 2 and 4). Although it is evident that the students used the terminology required by the teacher in these situations, it is reasonable to ask if the students understood the science content. Several scholars have shown how the IRE pattern implies a reproduction of factual knowledge and suggested that students need to be offered possibilities to argue, explain, discuss and generalise in order to gain a deeper understanding of science (Bleicher et al. 2003; Lemke 1990).

Occasionally, the whole class instruction did involve more explanatory dialogues. However, when participating in these conversations (lines 12-21 and 22-28), the students' language repertoire limited their possibilities to express themselves. In some occasions, verbal language was not enough and other resources were used. For example, when Kenan explained his idea about the differing results of the groups (lines 12-21), his utterances were constantly interrupted by hesitations and pauses. The word 'socket' was obviously not a part of Kenan's language repertoire. It was not until the teacher brought him a real bulb and he pointed out what he meant that he could make himself clear. Accordingly, it was the practical equipment that allowed Kenan to describe what he meant and allowed for continuity of the activity. The fact that bilingual students' language repertoire might limit their possibilities to communicate in science class was strengthened in the third transcript from whole class instruction (lines 22-28). Kenan made a longer utterance when talking about his own experience and the IRE pattern was less prominent. The hesitations and breaks in his utterance showed how his language repertoire in Swedish limited him from expressing himself.

The question is then whether these situations are unique for bilinguals or if it is possible that the words 'socket' and 'electricity' might not be a part of monolingual students' language repertoire as well? Of course, this is possible. Monolingual students might also have language limitations with words in the Swedish vocabulary. However, the purpose of this study is not to make a list of, or, give examples of words that are difficult exclusively for bilingual students. Instead, we have been demonstrating in this article how bilingual students' language repertoire limits their possibilities to make more advanced utterances in activities conducted monolingually. In addition, a study comparing monolingual and bilingual students' language use is not valid when adopting the theory of translanguaging. According to García (2009) such a comparison would imply having a monolingual view of bilingualism.

That bilingual students' language repertoire might limit their possibilities to communicate in a more advanced way has also been emphasised by Nygård Larsson (2011). Her study has shown how bilingual students' language proficiency might limit their possibilities to write more advanced texts in science. In particular, bilingual students' texts contained shorter descriptions and factual knowledge about scientific phenomena, whereas other qualities, for example, argumentation, discussions and generalisations, were often missing. The students in our study were 9-10 years old, and the lessons did not involve scientific knowledge on a higher level as in the mentioned study (Nygård Larsson 2011). Hence, our study contributes by showing how bilingual students' language proficiency may limit their possibilities to 
communicate not only when writing advanced science texts but also in verbal dialogues in primary school science (lines 11-21 and 22-28).

During the group activities (lines 29-49 and 50-64), there was a constant and fluid change between Turkish and Swedish as the students sharing the same minority language discussed the tasks at hand. Translanguaging and using the best available linguistic or concrete resources were evident in these situations, where the teacher was not in control of the dialogues. In the first example (lines 29-49), the students managed lighting the bulb, but they did not use the scientific terms (lamp, battery, battery holder etc.) to a great extent. Instead, it was the equipment itself that was the resource needed to perform the activity. The second example (lines 50-64), on the other hand, illustrates the naming of the used equipment. Although the students had the possibility to use both of their languages, the teacher's instructions were only in Swedish, and the focus of the activity became to determine what the words that the teacher had written on the whiteboard meant rather than discussing the materials' conductivity. One could argue that the absence of more scientific terms in the first example (lines 29-64) and the discussions of words rather than conductivity in the second one (lines 50-64) represent a lack of scientific meaning-making. However, what we do see is a continuous negotiation of what the words might mean and how to light the bulb by using Swedish, Turkish and manual gestures referring to the equipment and pointing to 'this one' that 'goes there'. We argue that this work is important for further scientific meaning-making. The equipment plays a significant role, as does the naming of objects, and this constitutes the ground for developing an understanding of science. Consequently, we claim that using all available resources is essential for scientific meaning-making. Meaning-making was also present in whole class situations, but mainly in terms of labelling parts of material and filling in the correct Swedish words (lines 1-21). However, conversations in which students' whole language repertoire was given space as working tools for discussing, negotiating and reflecting on scientific reasoning were often missing. Accordingly, students' language backgrounds and experiences from everyday contexts mediated by their minority languages become separated from the teacherled scientific meaning-making in Swedish. In other words, the scientific terms were used in whole class encounters (lines 1-11), whereas students' minority language was given room in the group activities (lines 29-64). Hence, meaning-making occurred in both whole class instruction and group work, but language use in the different forms of instruction became disconnected from each other.

\section{Conclusion}

Conducting bilingual science lessons is much more demanding in multilingual classes since it is impossible for teachers to speak all languages represented in their classrooms. However, bilingual students' minority language is an important resource for their meaning-making in science (Goldberg et al. 2009; Reyes 2009; Warren et al. 2001). This study has shown that it is possible to conduct bilingual science lessons in multilingual classes (29-49 and 50-64). The fact of several minority languages being represented in the same class is not a reason to abandon bilingual science education. Rather, considering the academic gap between monolingual and bilingual students' achievements (Lee and Luykx 2007; Nygård Larsson 2011), we argue that it is important to include bilingual students' minority language in multilingual classes in order to offer bilingual students increased opportunities to learn science. Accordingly, there is a need for explicit strategies on how to make use of scientific terms in both teacher-led dialogues and students' interactions where they used their whole language repertoire continuously. 


\section{Compliance with Ethical Standards}

Funding This study was funded by the Stockholm University, Department of Mathematics and Science Education.

Conflict of Interest The authors declare that they have no conflict of interest.

Open Access This article is distributed under the terms of the Creative Commons Attribution 4.0 International License (http://creativecommons.org/licenses/by/4.0/), which permits unrestricted use, distribution, and reproduction in any medium, provided you give appropriate credit to the original author(s) and the source, provide a link to the Creative Commons license, and indicate if changes were made.

\section{References}

Bellack, A., Kliebard, H., Hyman, R., \& Smith, F. (1966). The language of the classroom . New York: Teachers' College Press.

Blackledge, A., \& Creese, A. (2010). Multilingualism: a critical perspective. London: Continuum.

Bleicher, R., Tobin, K., \& McRobbie, C. (2003). Opportunities to talk science in a high school chemistry classroom. Research in Science Education, 33(3), 319-339.

Carlsen, W. S. (2007). Language and science learning. In S. K. Abell \& N. G. Lederman (Eds.), Handbook of research on science education (pp. 57-74). Mahwah, NJ: Lawrence Erlbaum Associates.

Cummins, J. (2000). Language, power and pedagogy: bilingual children in the crossfire. Clevedon: Multilingual Matters.

Cummins, J. (2005). A proposal for action: strategies for recognizing heritage language competence as a learning resource within the mainstream classroom. The Modern Language Journal, 89, 585-592.

Cummins, J. (2008). Teaching for transfer: challenging the two solitudes assumption in bilingual education. In N. H. Hornberger (Ed.), Encyclopedia of language and education (Vol. 5, 2nd ed., pp. 65-75). New York: Springer.

Dewey, J. (1925). Experience and nature. New York: Dover Publications Inc..

Dewey, J. (1934). Art as experience. New York: Perigee Books, Berkeley Publishing Group.

Dewey, J. (1938). Experience and education. New York: Simon \& Schuster.

Erduran, S., Simon, S., \& Osborne, J. (2004). TAPping into argumentation: developments in the application of Toulmin's argument pattern for studying science discourse. Science Education, 88(6), 915-933.

García, O. (2009). Bilingual education in the 21st century: a global perspective. Malden, MA: Blackwell Pub.

García, O. (2011). Theorizing translanguaging for educators. In C. Celic \& K. Seltzer (Eds.), Translaguaging: a CUNY-NYSIEB guide for eductors (pp. 1-6). New York: CUNY-NYSIEB, The Graduate Center \& The City University of New York.

García, O., \& Sylvan, C. E. (2011). Pedagogies and practices in multilingual classrooms: singularities in pluralities. The Modern Language Journal, 95(3), 385-400.

Gibbons, P. (1998). Classroom talk and the learning of new registers in a second language. Language and Education, $12(2), 99-118$.

Gibbons, P. (2008). "It was taught good and I learned a lot": intellectual practices and ESL learners in the middle years. Australian Journal of Language and Literacy, 31(2), 155-173.

Goldberg, J., Enyedy, N., Welsh, K. M., \& Galiani, K. (2009). Legitimacy and language in a science classroom. English Teaching: Practice and Critique, 8(2), 6-24.

Harré, R., \& Gillett, G. (1994). The discursive mind. Thousand Oaks, Calif: Sage.

Kelly, G. J., McDonald, S., \& Wickman, P. O. (2012). Science learning and epistemology. In K. Tobin, B. J. Fraser, \& C. J. McRobbie (Eds.), Second international handbook of science education. Dordrecht: Springer.

Lave, J., \& Wenger, E. (1991). Situated learning. Legitimate peripheral participation. Cambridge: Cambridge University Press.

Lee, O. (2005). Science education with English language learners: synthesis and research agenda. Review of Educational Research, 75(4), 491-530.

Lee, O., \& Luykx, A. (2007). Science education and student diversity: race/ethnicity, language, culture, and socioeconomic status. In S. K. Abell \& N. G. Lederman (Eds.), Handbook of research on science education (pp. 171-197). Mahwah, N.J: Lawrence Erlbaum Ass. Publ.

Lemke, J. L. (1990). Talking science: language, learning, and values. Norwood, N.J: Ablex.

Lemke, J. L. (1998). Multimedia demands of the scientific curriculum. Linguistics and Education, 10(3), 247-271.

Lindholm-Leary, K., \& Graciela, B. (2006). Academic achievement. In F. Genesee, K. Lindholm-Leary, W. Saunders, \& D. Christian (Eds.), Educating English language learners: a synthesis of research evidence (pp. 176-222). New York: Cambridge University Press. 
McNeill, K. L., \& Pimentel, D. S. (2010). Scientific discourse in three urban classrooms: the role of the teacher in engaging high school students in argumentation. Science Education, 94(2), 203-229.

Norris, S. P., \& Phillips, L. M. (2003). How literacy in its fundamental sense is central to scientific literacy. Science Education, 87(2), 224-240.

NTA - Naturvetenskap och Teknik för Alla (Science and Technology for Children) (2016). http://www. ntaskolutveckling.se.

Nygård Larsson, P. (2011). Biologiämnets texter: text, språk och lärande i en språkligt heterogen gymnasieklass (The texts in biology. Text, language and learning in a linguistic heterogeneous upper secondary class). Malmö: Malmö högskola.

Pica, T. (2011). Second language acquisition research. Applied and applicable orientations to practical questions and concerns. In E. Hinkel (Ed.), Handbook of research in second language teaching and learning (Vol. 2, pp. 257-273). Mahwah, N.J: Erlbaum Associates.

Reyes, I. (2009). English language learners discourse strategies in science instruction. Bilingual Research Journal, 31(1-2), 95-114.

Rogoff, B. (1990). Apprenticeship in thinking: cognitive development in social context. Oxford: Oxford University Press.

Salleh, R., Venville, G. J., \& Treagust, D. F. (2007). When a child describes living things: an analysis of conceptual understandings from a language perspective. Research in Science Education, 37(3), 291-312.

Skutnabb-Kangas, T. (1981). Bilingualism or not: the education of minorities. Clevedon: Multilingual Matters.

Snively, G., \& Corsiglia, J. (2001). Discovering indigenous science: implications for science education. Science Education, 85(1), 6-34.

Stevenson, A. (2013). How fifth grade Latino/a bilingual students use their linguistic resources in the classroom and laboratory during science instruction. Cultural Studies of Science Education, 8(4), 973-989.

Säljö, R. (2000). Lärande i praktiken. Ett sociokulturellt perspektiv (Learning in practice. A sociocultural perspective). Stockholm: Bokförlaget Prisma.

The Swedish National Agency for Education (2008). Med ett annat modersmål-elever i grundskolan och skolans verksamhet (With another mother tongue - students in elementary school and school activities). Stockholm: Skolverket /Fritzes.

The Swedish National Agency for Education (2016a). Tabell 8A (Table 8A). http://www.skolverket.se/statistikoch-utvardering/statistik-i-tabeller/grundskola/skolor-och-elever.

The Swedish National Agency for Education (2016b). Tabell 1, 9A and 21A (Tables 1, 9A and 21A). http://www. skolverket.se/statistik-och-utvardering/statistik-i-tabeller/grundskola/provresultat.

The Swedish National Agency for Education (2016c). Tabell 5, 10A and 22A (Tables 5, 10A and 22A). http://www.skolverket.se/statistik-och-utvardering/statistik-i-tabeller/grundskola/provresultat.

The Swedish National Agency for Education (2016d). Tabell 26A, 27A and 28A (Table 26A, 27A and 28A). http://www.skolverket.se/statistik-och-utvardering/statistik-i-tabeller/grundskola/provresultat.

The Swedish Research Council (2016). http:/www.vr.se/inenglish.4.12fff4451215cbd83e4800015152.html

Warren, B., Ballenger, C., Ogonowski, M., Rosebery, A. S., \& Hudicourt-Barnes, J. (2001). Rethinking diversity in learning science: the logic of everyday sense-making. Journal of Research in Science Teaching, 38(5), 529-552.

Webb, P., \& Treagust, D. (2006). Using exploratory talk to enhance problem-solving and reasoning skills in grade-7 science classrooms. Research in Science Education, 36(4), 381-401.

Wellington, J., \& Osborne, J. (2001). Language and literacy in science education. Buckingham: Open University Press.

Wertsch, J. V. (1993). Ett sociokulturellt perspektiv på mental handling (A sociocultural perpective on mental action). Spovstudier av den pedagogiska väven. Institutet för pedagogik och textforskning. Högskolan Sundsvall/Härnösand, 20, 2-12.

Wertsch, J. V. (1995). The need for action in sociocultural research. Cambridge, UK: Cambridge University Press.

Wickman, P. O. (2004). The practical epistemologies of the classroom: a study of laboratory work. Science Education, $88(3), 325-344$.

Wickman, P. O. (2006). Aesthetic experience in science education: learning and meaning-making as situated talk and action. Mahwah, N.J: Erlbaum Associates.

Wickman, P. O., \& Östman, L. (2002). Learning as discourse change: a sociocultural mechanism. Science Education, 86(5), 601-623.

Wittgenstein, L. (1953). Filosofiska undersökningar (Philosophical investigations). Stockholm: Thales. 